MLM-2371

Mound Laboratory Activities on the Removal of Plutonium and Uranium from Wastewater Using Bone Char

Doye E. Blane and Elton L. Murphy

September 30, 1976

\section{MLM-2371}

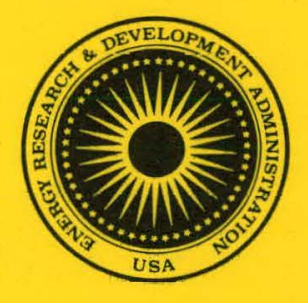

Monsanto 


\section{DISCLAIMER}

This report was prepared as an account of work sponsored by an agency of the United States Government. Neither the United States Government nor any agency Thereof, nor any of their employees, makes any warranty, express or implied, or assumes any legal liability or responsibility for the accuracy, completeness, or usefulness of any information, apparatus, product, or process disclosed, or represents that its use would not infringe privately owned rights. Reference herein to any specific commercial product, process, or service by trade name, trademark, manufacturer, or otherwise does not necessarily constitute or imply its endorsement, recommendation, or favoring by the United States Government or any agency thereof. The views and opinions of authors expressed herein do not necessarily state or reflect those of the United States Government or any agency thereof. 


\section{DISCLAIMER}

Portions of this document may be illegible in electronic image products. Images are produced from the best available original document. 


\title{
Mound Laboratory Activities on the Removal of Plutonium and Uranium from Wastewater Using Bone Char
}

\author{
Doye E. Blane and Elton L. Murphy
}

Issued: September 30, 1976

\section{NOTICE}

This report was prepared as an account of work sponsored by the United States Government. Neither the United Stales nor the Uniled States Energy Research and Development Administration, nor any of their employees, nor any of their contractors, subcontractors, or their employees, makes any warranty, express or implied, or assumes any legal liability or responsibility for the accuracy, com-

pleteness or usetulness of any information, apparatus, product or process disclosed or represents that its use would not infringe privately owned rights.

PRINTED IN THE UNITED STATES OF AMERICA

Available from

National Technical Information Service

U.S. Department of Commerce

5285 Port Royal Road

Springfield, Virginia 22161

Price: Printed Copy $\$ 3.50$ : Microfiche $\$ 2.25$

\section{MONSANTO RESEARCH CORPORATION}

A Subsidiary of Monsanto Company

\section{MOUAD IABORATORY}

Miamisburg, Ohio

45342

operated for

\section{UNITED STATES ENERGY RESEARCH AND DEVELOPMENT ADMINISTRATION}

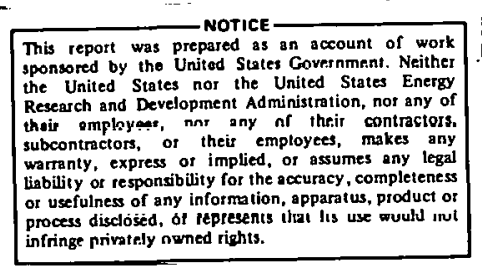

U. S. Government Contract No. EY-76-C-04-0053 


\section{Introduction}

Pilot plant studies sponsored by the Division of Military Application (DMA) to treat Mound Laboratory's low risk waste streams with bone char columns have been completed. This project was to accomplish the following: acquire engineering data such as flow rates, adsorption capacity, and optimum particle size for designing a tertiary treatment system, and (2) optimize the primary waste treatment process using coagulants and flocculants.

Bone char, a natural product made from granulated cattle bone, is a form of calcium hydroxyapatite $\left[\mathrm{Ca}_{1}\left(\mathrm{PO}_{4}\right)_{6}(\mathrm{OH})_{2}\right]$ and contains a small amount of carbon. It is characterized by a high porosity and good resistance to abrasion and crushing:

Because plutonium and other actinides can be precipitated as phosphates from weakly acidic, neutral or alkaline solutions, it appeared possible to use an insoluble phosphate adsorbent such as bone char to remove them from waste streams.

Preliminary column studies and a description of Mound Laboratory's radioactive low-level waste treatment facility can be found in a previous report. ${ }^{1}$

\section{Data and Results}

\section{FLOW RATE STUDIES AT 1.5 GAL/MIN}

The final pilot studies using bone char were conducted on the filtrate or effluent from a sandfilter in the waste Treatment Facility. The sandfilter effluent was pumped through a 15- $\mu$ filter which was followed by a column of bone char (Figures 1 and 2). A diagram of the column used in these studies is shown in Figure 3 . Previous column studies included in the aforementioned report ${ }^{1}$. were carried out

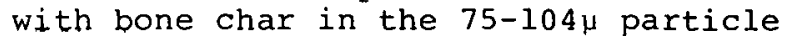
size range. This material size was obtained by grinding, sieving and hydraulic separation, a tedious task. It was decided to conduct the final studies on the "as received" bone char for a two-fold purpose: (1) to exclude the sizing operation and, (2) to possibly eliminate the higher pressure drops across the bed experienced with the smaller particle sizes. In the current study," "as received" bone char was used and the particle size distribution is shown in Figure 4. From this graph, it can be seen that the average particle size is about $1.1 \mathrm{~mm}$.
Initial column studies on the sandfilter effluent were begun with 110 lbs of "as received" bone char whose bed dimensions were $24 \mathrm{in.} \mathrm{high} \mathrm{by} 15$ in. diameter. A flow rate of 1.4 to $1.6 \mathrm{gal} / \mathrm{min}$ was maintained.

As shown in the flow diagram (Figure 2) the sandfilter effluent $(\mathrm{pH}=6.5-7.5)$ was pumped through a filter $(15 \mu)$, then into the bone char column. Samples were taken before and after the filter and after the column. A 10-ml sample of each was counted for $100 \mathrm{~min}$ in a Packard Model 2211 Liquid Scintillation spectrometer. Data from this particular run is compiled in Table 1 . Over 22,000 gal of the sandfilter effluent were pumped through the column with an average decontamination factor (DF) of 5.8. It can be discerned that the DF varies proportionally to the radioactive concentration of the column feed solution. However, there appears to be a lower limit of decontamination in the range of 0.1 to $0.3 \mathrm{dis} / \mathrm{min} / \mathrm{ml}$ for the plutonium in the waste stream. It should also be noted that the $15-\mu$ filter had a negligible effect on the removal of alphaemitting radionuclide. The pressure drop across the bed was near zero at this fllow rate.

Another run was attempted at $10 \mathrm{gal} / \mathrm{min}$ through a fresh 24-in. high bed, but had to be terminated because the pump capacity was too low and overheated due to the higher pressure drop. The old bed was replaced with a fresh one which was only 12 in. high and the flow was reduced to $5 \mathrm{gal} / \mathrm{min}$.

\section{FLOW RATE STUDIES AT 5 GAL/MIN}

During this run the pressure drop ranged from 8 to 10 psig. Uver 100,000 yal of sandfilter effluent were pumped through 60 lbs of bone char before saturation as plotted in Figure 5. The DF's averaged from 3 to 4 for approximately $60 \%$ of the run. In order to determine the adsorptive capacity. of the bone char, the amount of plutonium adsorbed by the bed was plotted versus volume (Figure 6 ) and the area under the plot calculated. This value was determined to be $8,673 \mathrm{dis} / \mathrm{min}$ of plutonium per gram of bone char $\left(3.9 \times 10^{-3}\right.$ $\mu \mathrm{Ci} / \mathrm{g})$. The feed solution had a concentration range of 0.3 to $1.9 \mathrm{dis} / \mathrm{min} / \mathrm{ml}$. In a small scale study using $1.88 \mathrm{~g}$ of bone char, 3.45 gal of waste water averaging $3.8 \mathrm{dis} / \mathrm{min} / \mathrm{ml}$ was necessary to saturate the bed. From this data, the total capacity of the bone char was calculated to be $5.1 \times 10^{-3} \mu \mathrm{Ci} / \mathrm{g}$. 


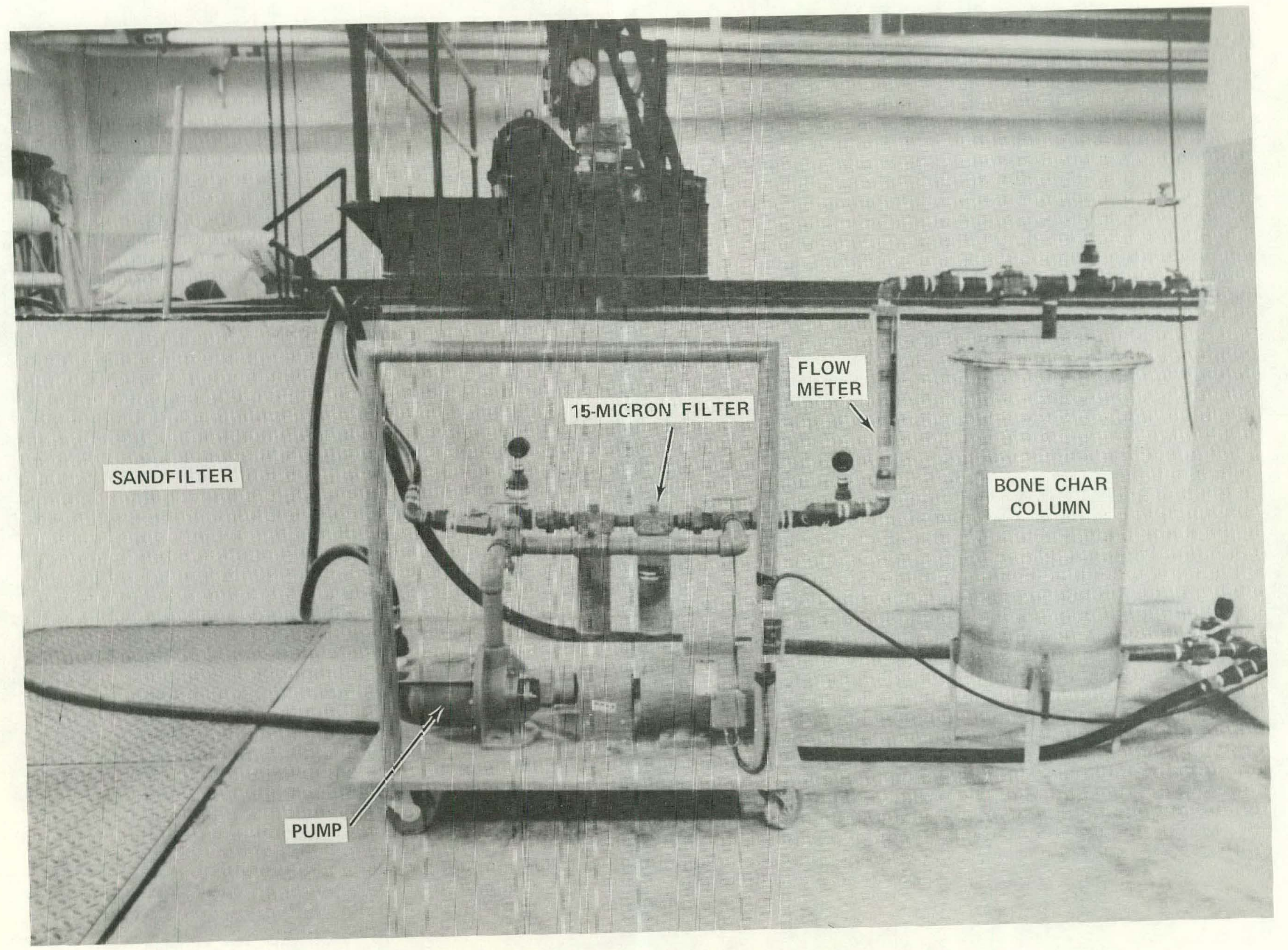

FIGLRE I - ECne char pilot unit anc̈ sandfilter. 


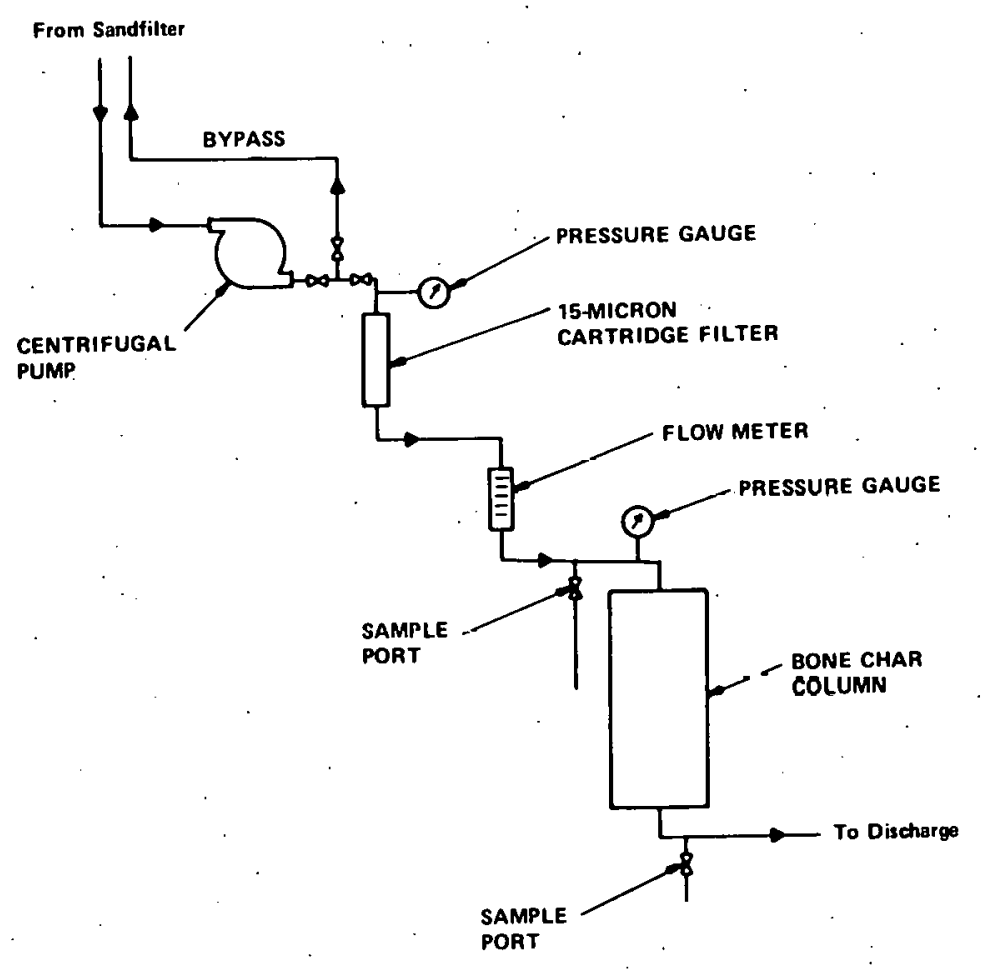

FIGURE 2 - Flow diagram of bone char pilot plant.

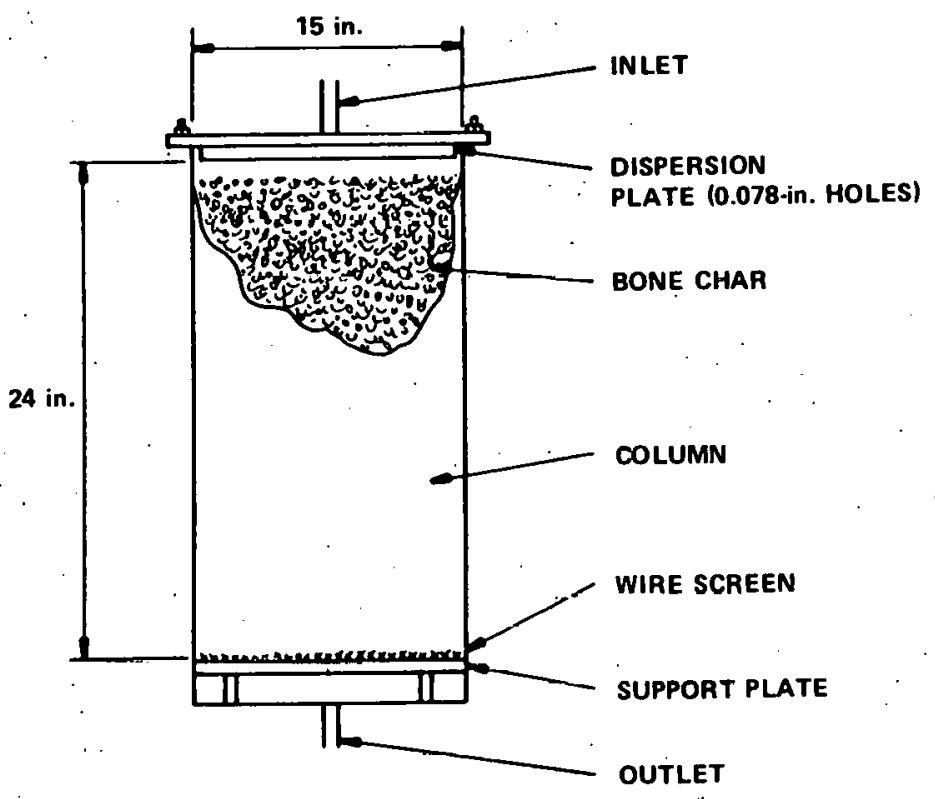

FIGURE 3. - Diagram of bone char column.

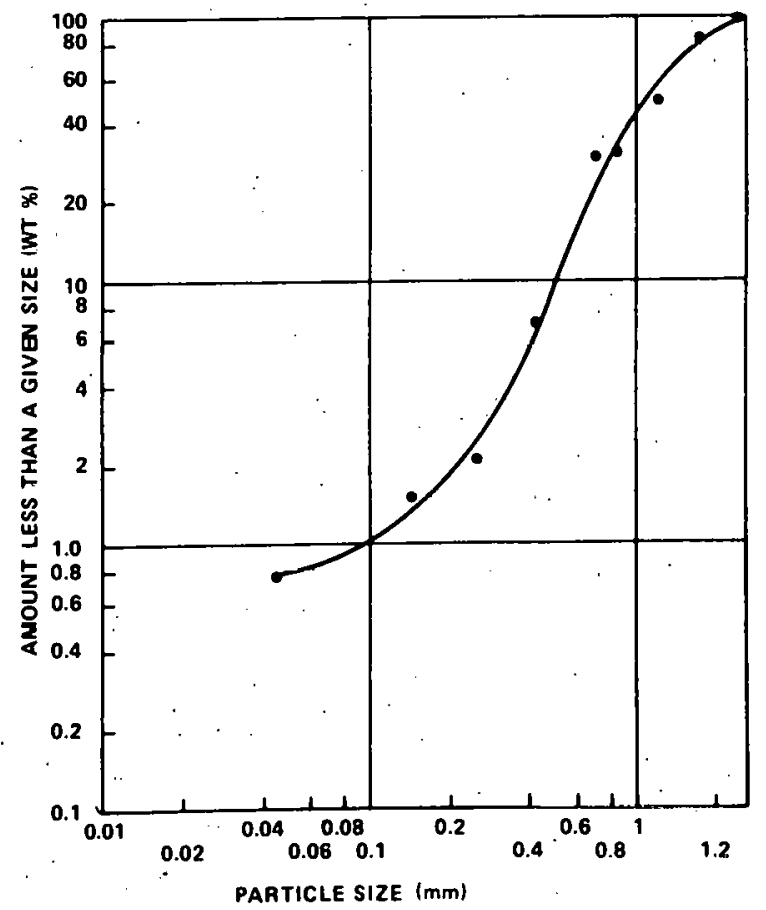

FIGURE 4 - particle size distribution of bone char. 
Table 1

PILOT RUN WITH A.24 IN. HIGH BY 15 IN. DIAMETER BONE CHAR COLUMN*

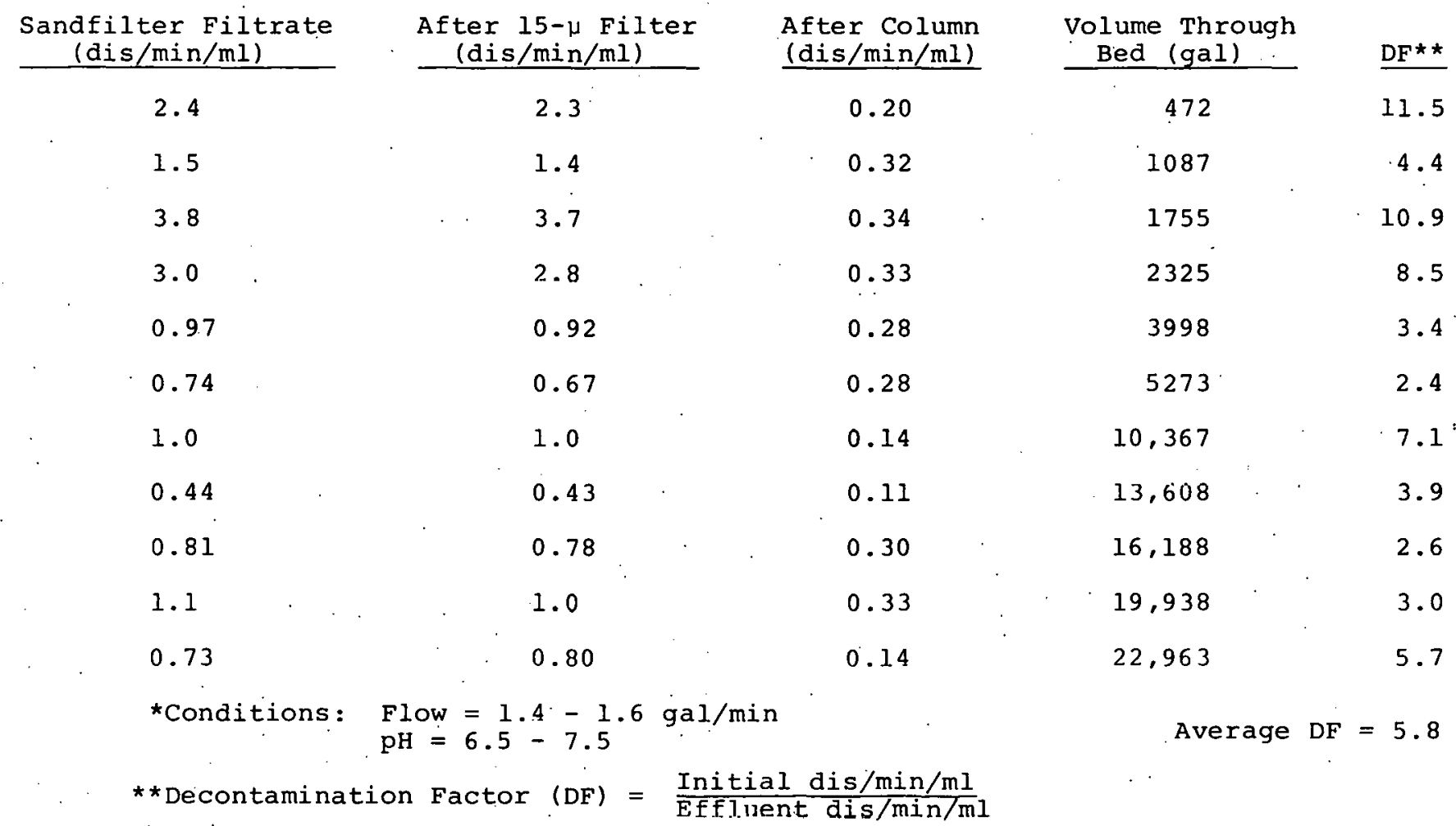

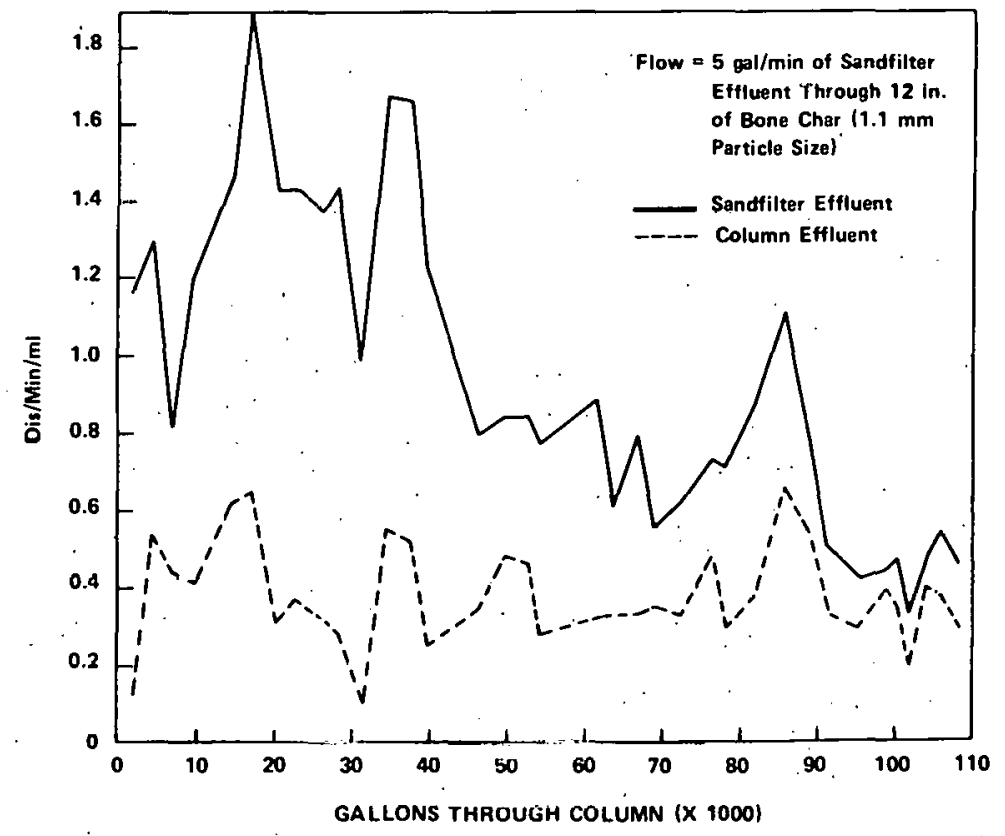

FIGURE 5 - Radinactivity in sandfilter and colum effluents. 


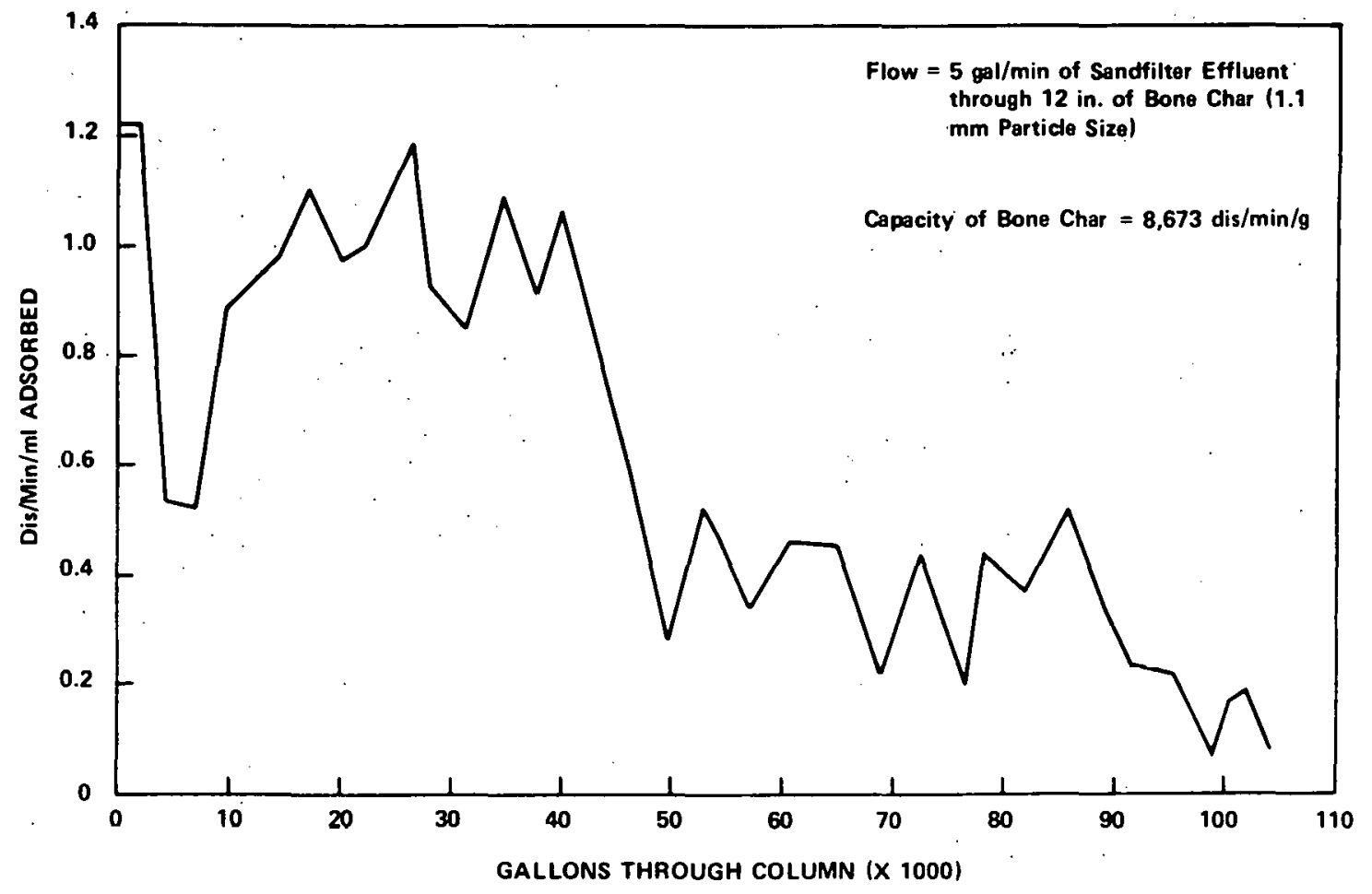

FIGURE 6 - Radioactivity removed at 5 gal/min flow rate.

Alpha-pulse-height analyses were made on samples of the sandfilter and the column effluents to determine if plutonium-238 was the only alpha-emitting isotope removed by the bone char. Results of this analysis (Table 2) showed that uranium-233 was also present and bone char had nearly equal affinity for this radionuclide. This result should have been expected because actinides form insoluble phosphate compounds.

Figure 7 is a typical alpha-pulse-height spectrum of the waste stream showing the various radionuclides present. The two peaks on the extreme right are that of plutonium-236 and the less distinguishable one on the extreme left is uranium236. Both isotopes were used as tracers.
As shown by the spectrum, plutonium-238 is the major contaminant (second peak from the right) in the waste stream with smaller amounts of plutonium-239 (to the left of plutonium-238) and uranium-233.

\section{FLOW RATE STUDIES AT $10 \mathrm{GAL} / \mathrm{MIN}$}

Because of pumping capacity, an earlier pilot study at a $10-\mathrm{gal} / \mathrm{min}$ flow rate had to be terminated. A pump with a higher capacity was used and the results of this study through a 24-in. bed are shown in Figure 9. Another modification was made by increasing the holes in the dispersion plate from 0.031 in. to 0.078 in. to accommodate the increased flow rate. This modification decreased the pressure drop across the 24-in. bed to about 18-20 psig.

Table 2

ALPHA PULSE-IIEIGIT RESULTC ON THE SANDFILTER AND COTIIMN FFFLUENTS

\begin{abstract}
Before Bone Char Column
\end{abstract}

$$
\begin{array}{rr}
\text { Pu-238 } & (0.68 \mathrm{dis} / \mathrm{min} / \mathrm{ml}) \\
\mathrm{U}-233 & (0.24 \mathrm{dis} / \mathrm{min} / \mathrm{ml})
\end{array}
$$

\section{Nfter Bone Char Column}

$$
\begin{array}{rr}
\text { Pu-238 } & (0.20 \mathrm{dis} / \mathrm{min} / \mathrm{ml}) \\
\mathrm{U}-233(0.08 \mathrm{dis} / \mathrm{min} / \mathrm{ml})
\end{array}
$$

Decontamination Factor
3.4
3.0 

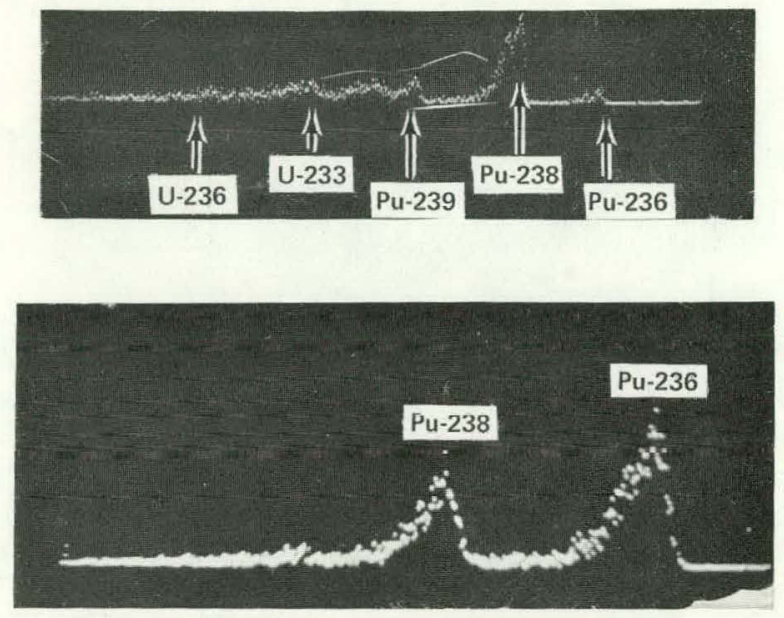

Before
FIGURE 7 - Alpha-pulse height spectra showing radionuclides in waste stream.

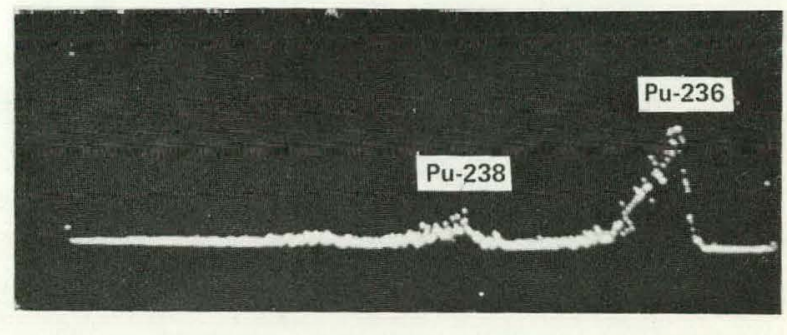

After

FIGURE 8 - Alpha-pulse height spectra before and after the bone char column.

The column feed ranged from 0.29 to 0.45 $\mathrm{dis} / \mathrm{min} / \mathrm{ml}$ and the concentration average was about $0.4 \mathrm{dis} / \mathrm{min} / \mathrm{ml}$, while the radioactivity level in the column effluent ranged from 0.1 to $0.27 \mathrm{dis} / \mathrm{min} / \mathrm{ml}$ with an average of $0.2 \mathrm{dis} / \mathrm{min} / \mathrm{ml}$. As shown by the graph, over 55,000 gal of sandfilter effluent was pumped through the column before saturation and the decontamination factor averaged about 2 for $90 \%$ of the run.

Comparing the longevity of this run with that in Figure 5, the latter had a total volume of over 100,000 gal before saturation which is nearly double the total volume from the $10-\mathrm{gal} / \mathrm{min}$ run. This difference can possibly be explained by the increased amount of radioactivity in the column feed which averaged at least 2 to 3 times higher than the feed in 10-gal/min run.

Figure 8 shows alpha-pulse-height spectra of the sandfilter effluent before entering the column and the column effluent. The peaks on the right of each photo are that of plutonium-236 which was used as a tracer and the most distinquishable one to the left of the plutonium-236 is plutonium-238. Less distinguishable are the uranium-233 peaks which are to the left of the plutonium-238.
Flow rates of 5 and $7.5 \mathrm{gal} / \mathrm{min}$ were made on the 24-in. bed used in the $10-\mathrm{gal} / \mathrm{min}$ flow rate study but little differences in the DF's were noted. It appeared that a lower limit for the removal of the radioactivity had again been reached. This limit appears to be about $0.4 \mathrm{dis} / \mathrm{min} / \mathrm{ml}$ and at this point the bone char capacity for the radionuclides drops off to almost zero.

\section{COLUMN DESIGN FOR TERTIARY TREATMENT}

The criteria used in designing the fullscale treatment system was based on data obtained primarily from the $10-\mathrm{gal} / \mathrm{min}$ pilot study at a 24-in. bed height with an inner diameter of 15 in. A column with a cross-sectional area of $6.1 \mathrm{ft}^{2}$ will be necessary to treat the maximum flow of 50 $\mathrm{gal} / \mathrm{min}$ from the sandfilter. This crosssectional area was obtained by increasing the area of the pilot column 5-fold. However, two columns with an inner diameter of 2 ft would have a total cross-sectional area of $6.28 \mathrm{ft}^{2}$ which is more than adequate to accommodate a $50-\mathrm{gal} / \mathrm{min}$ flow.

The 24-in. bed yielded DF's of 2 or more (Fiqure 9) up to approximately 50,000 gal total throughput of sandfilter effluent. 


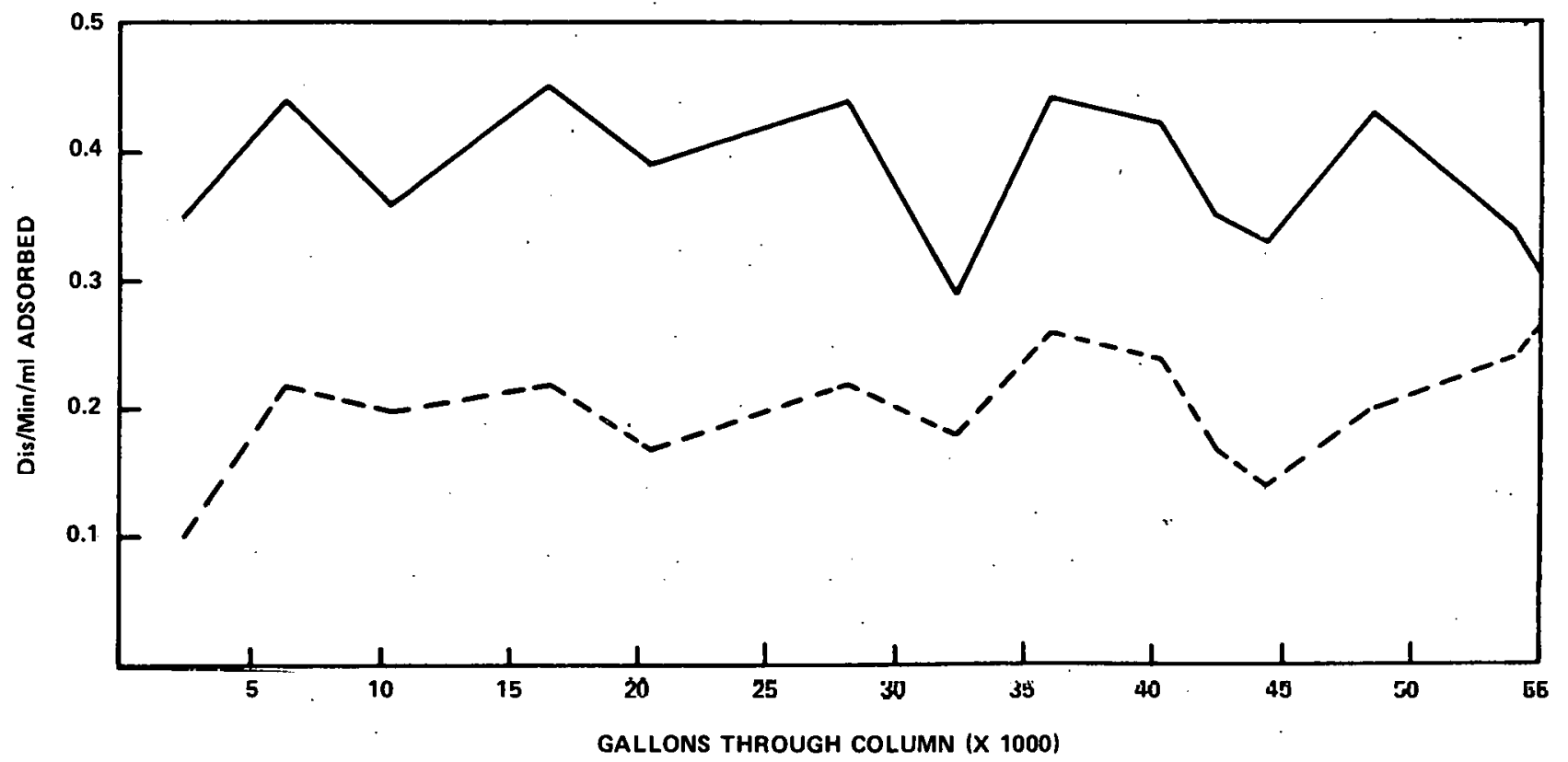

Flow $=10 \mathrm{gal} / \mathrm{min}$ of Sandfilter Filtrate

Through 24 in. of Bone Char

(1.1 mm Particle Size)

- Before Column

- - After Column

FIGURE 9 - Radioactivity removed at $10 \mathrm{gal} / \mathrm{min}$ flow rate.

Thercfore, columns with the same bed height and 5 times the cross-sectional area should theoretically handle 250,000 gal of sandfilter effluent with an equivalent radioactivity level before the DF drops below 2. For a bed height 1.75 times the theoretical one mentioned above, approximately 440,000 gal should be the total throughput before the DF falls below 2.

From studies at the same flow rate but at different bed heights (residence times), the controlling factor appeared to be the velocity of the stream rather than bed height, so it is assumed that an increase in bed height at the same flow rate will increase the total throughput volume proportionally without altering lie DF significantly.

The design for the full-scale treatment of $50 \mathrm{gal} / \mathrm{min}$ flow will be two columns whose bed dimensions are $3.5 \mathrm{ft}$ high by 2 ft in diameter. A diagram of one of the columns is shown in Figure 10. Each of the columns will contain approximately
500 lbs of bone char and at least 440,000 gal of sandfilter effluent can be treated with a DF of 2 when the feed concentration is at $0.4 \mathrm{dis} / \mathrm{min} / \mathrm{ml}$. It is estimated that the beds will be changed at about 3-month intervals or four times a year. A flow diagram of the bone char tertiary treatment system is illustrated in Figure 11. Pressure drops across the bed at the 1 and $2 \mathrm{ft}$ bed heights and $10 \mathrm{gal} / \mathrm{min}$ flow showed the pressure varied proportionaliy to the bed height. It is estimated that the drop across a bed $3.5 \mathrm{ft}$ high will be in the 40-50 psig range. Compaction of the bed will probably account for the pressure drop being closer to 50 psig.

\section{Conclusion}

Data previously mentioned were used to design two bone char columns $3.5 \mathrm{Fl}$ high by 2 ft in diameter. These columns, a tertiary treatment system, will be used to maintain an alpha-counting level in the range of 0.1 to $0.2 \mathrm{dis} / \mathrm{min} / \mathrm{ml}$ or less in Mound Laboratory's low-level radioactive effluent stream. 


\section{Future Plans}

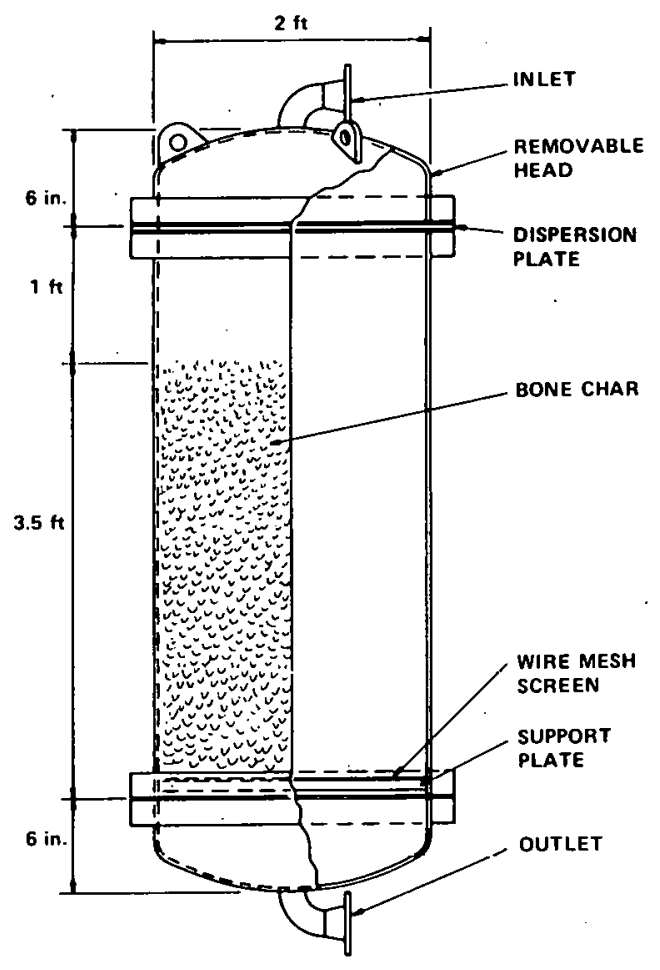

FIGURE 10 - Column design for tertiary waste treatment.
Preliminary studies have been initiated using bone char columns as a primary treatment on high-level caustic scrub and residual solutions. Small scale column studies have yielded DF's in the $10^{4}$ to $10^{5}$ range with "as received" bone char. Primary treatment of the solutions with bone char yielded a waste stream which could be treated in the low-level waste Treatment Facility thereby decreasing solid waste generation. Currently, about thirty-five 55-gal drums of solid waste are generated each month to absorb 350 gal of high-level caustic solution. In the low-level waste Treatment Facility less than one drum of sludge would be generated in treating 350 gal of waste solution. Therefore, it is estimated that a $30: 1$ reduction in solid waste generation can be realized using the bone char columns as a primary treatment. About one year absorption life is expected from a 100-1b bone char column (less than one 55-gal drum of solid waste).

\section{Reference}

1. D. E. Blane and E. L. Murphy, Mound Laboratory Activities on the Removal of Radionuclides from wastewater Using Bone Char, MLM-2244 (September

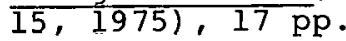

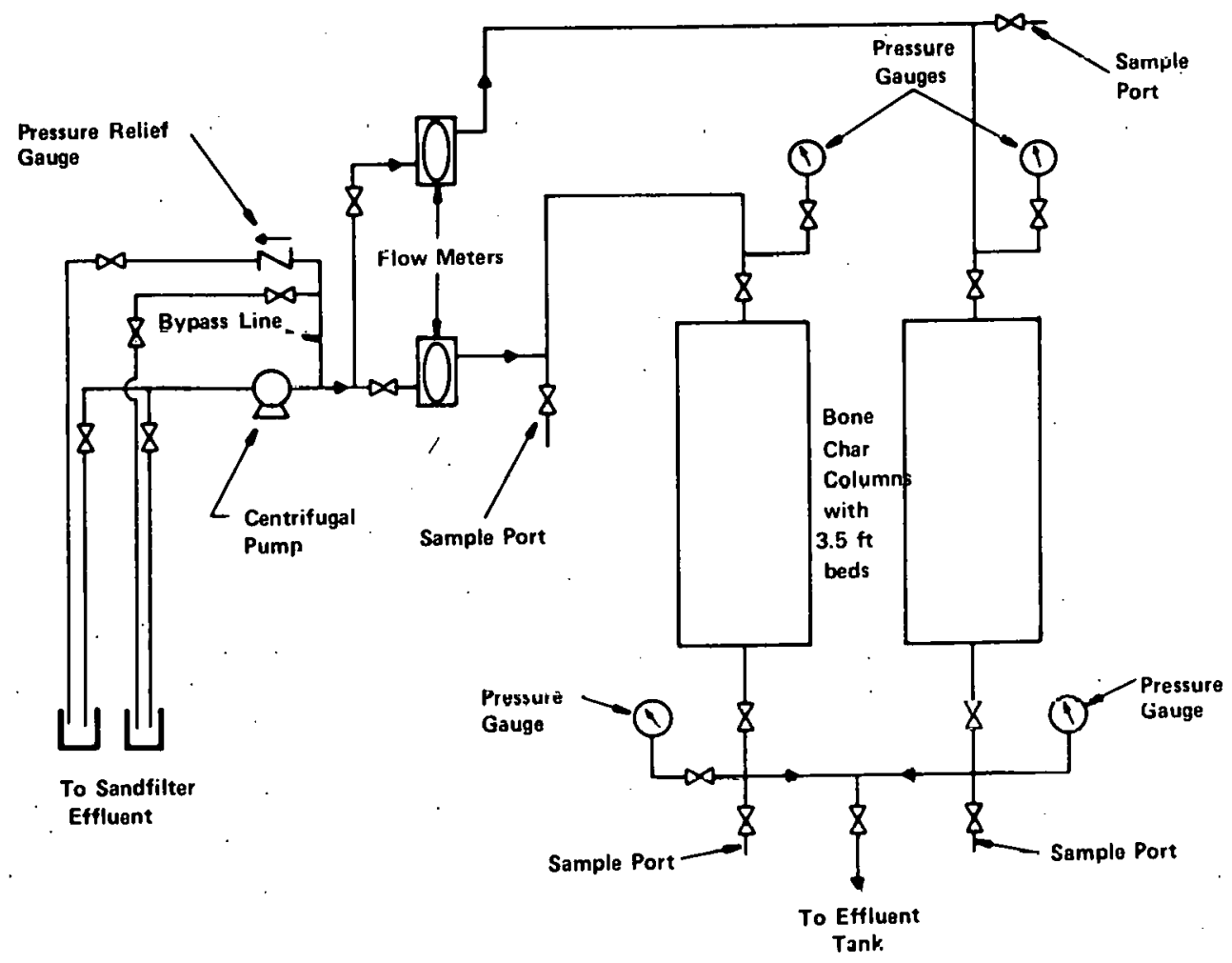

FIGURE 11 - Flow diayram for full-scale tertiary treatment of sandfilter effluent. 


\section{Distribution}

\section{External}

TIC, UC-70 (211)

R. R. Fredlund, ALO

C. P. Sutter/R. N. Diebel, ARHCO

H. W. Mattson, St. Louis

Technical Report Library, st. Louis

center for Atomic Energy Documentation (ZAED)

Karlsruhe, Germany

Dr. Peter J. Dyne, Atomic Energy of Canada Ltd.

R. K. Flitcraft, MRC

J. A. Chacon, DAO

Consultants:

W. E. Moddeman

Research Institute

University of Dayton

Dayton, Ohio 45406

Dr. D. White

Dept. of Chemistry

University of Pennsylvania

Philadelphia, Pennsylvania 19104

Dr. R. N. Zare

Dept. of Chemistry

Columbia University

New York, New York 10025

Internal
D. E. Blane (3)
W. T. Cave
L. V. Jones
C. W. Huntington
D. P. Kelly
H. W. Kirby
T. W. Knenst., Ir.
B. R. Kokenge

D. F. Luthy,
J. R. McClain
E. T.. Murphy (3)
L. B. Stevens
J. E. Todd
R. E. Vallee
Library (15)
Fublications (15) 